日本組織学記録, 卷 19, 号 3 (昭和 35 年 5 月). 頁 $411-436$.

Arch. hist. jap. Vol. 19, n. 3 (May 1960). S. 411-436.

\author{
群馬大学医学部精神神経科学教室 (主任: 台 弘教授) \\ Dept. of Neuro-Psychiatry, School of Med., Gunma Univ., Maebashi
}

(Director: Prof. H. UTENA).

\title{
泰髄神経節細胞の電子顕微鏡的研究.
}

\section{Electron Microscope Studies on the Spinal Ganglion Cells.}

\author{
秋山洋 一 Yoichi AKIYAMA.
}

(Received December 6, 1959.)

近時, 電子顕微鏡による細胞超微細構造の研究は, 短時日の間に格段の進歩を 遂げ，從来光学顕微鏡によっては末知とされていた多くの事象が，次々と明るみ

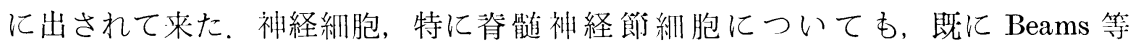
(1952), Hess (1955), Hossack と Wyburn (1954), 本陣 (1957), Anderson と van Breemen (1958), その他の電子顕微鏡的研究が報告されている。しかしながら， 神経細胞に特に多量に含有されているリボ核酸 (RNA) の超微形態学的な検討は, まだ充分でない，RNA を多量に保有する細胞構造として，神経細胞には，よく発 達した核小体と Nissl 小体が存在する。乙の両者は，光学顕微鏡的には多くの罚 合互に類似した染色性を示すが，その超微細棈造は甚だ異っている.

核小体は, 古くは単純な均質無棈造な物質塊とのみ考えられていたが, Estable と Sotelo (1951) に至って, 初めて核小体内に微絸な棈造の存在することが, 鍍 銀標本の光学顕微鏡的観察によって明らかにされ, 彼等は核小体の構成要素とし て, 'nucleolonema'と ‘pars amorpha'の2 部を区別した。これらの構造の存在 は，次いで電子顕微鏡によって実訴された（Borysko と Bang 1952, Bernhard 等: 1952, 1955, Horstmann とKnoop 1957, 黑住と秋山 1958, Yasuzumi 等 1958)。最 近 Kurosumi 等 (1959) は, 人の汗腺細胞に於て, 所謂 nucleolonema が螺旋状の 絒糸 (primary nucleolonema) から成ることを指摘し, 彷米加ら nucleolonema よばれたものを secondary nucleolonema とした。しかし，これが巾空螺旋である か，充実螺旋であるか，或はほぼ何本の細糸から成っているか等については，㺫 瞭にされていない.

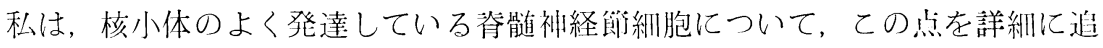
䆓し, 又核小体と Nissl 小体との超微細構造を, 比較检討した。 Nissl 小体が所謂 rough surfaced $の$ endoplasmic reticulum に属するととは, Palay と Palade (1955) によって詳細に記述され，その後他の研究者屯概ねこの説に從っている．しかし 私の観察によれば，神経細胞の塩基好性物質は，他種絒胞，例えば腺細胞，形質 細胞或は線維芽絪胞等に見られる endoplasmic reticum（ergastoplasm）とは根本 的に異った超微細構造を示す。私はこれら細胞内核蛋白棈造が, 細胞の分化及び 
機能に伴って, 特異な発達と形態配列を示すととを明らかにし, 神経練胞におけ る，乙れらの物体の立体棈造を明確にしようと試みた。併せて神経細胞に於ける 各種微細構造, 例えば糸粒体, Golgi 装置, 神経微原線維等の超微形態を記載し, 将来行われるであろう実験的研究, 並びに病的材料の電子顕微鏡的研究に対して, 有用な基礎を提供しようと試みたあのである。

\section{I. 研究材料 と方法.}

主たる材料として使用したのは，ウサギ及びイヌの腰椎脊䯑迫神経郎であるが， その他にウサギの小脳，手術時に採职した人の大脳皮質等も参考しして微祭し た。

動物から採取された被検材料は，小片として可及的速やかに，下記䍏定液内に 投入，更に同定の途中にて約 $1 \mathrm{~mm}$ 立方の大きさに細切された。同定液は phosphate buffer 又は acetate veronal により $\mathrm{pH} 7.4$ に緩衡された $1 \% \mathrm{OsO}_{4}$ 液を用い， 圆定時間は 3 時間である.

周定終了後, 蒸溜水で短時間水洗後, 上昇アルコール列により脱水, n-butyl methacrylate と methyl methacrylate の $8: 2$ 又は, $7: 3$ の混合物巾に包埋した. 重合促進触媒としては，過酸化ベンゾイルを $2 \%$ の制に添加した。

超薄切片の作製は，JUM-4 型ミクロトーム（熱膨脹式）に Latta-Hartmann 型 ガラスナイフを自製装着し，0.05一0.03 用した電子顕微鏡は，JEM-3 型で，加速電压 $50 \mathrm{kv}$ ，対物紋り口径 $0.05 \mathrm{~mm}$ であ る. 写真は 2,000-6,000 倍で撮影, 後に光学的に所要の倍率に引伸した。

上記の電子顕微鏡材料の他に，同洔に光学顕微鏡材料屯伴せてとり．Zenter， Levi，Da Fano 巨液，亜砒酸フォルモール等の各種间定液を使用し，トルイジン ブルーによるNissl 氏染出, ヘマトキシリンーエオジン染色, Heidenhain 氏鉄へマ トキシリン染色, Golgi 及び Da Fano 鍍銀標本等を作り, 此較観察に供した。

\section{II. 所見と考察.}

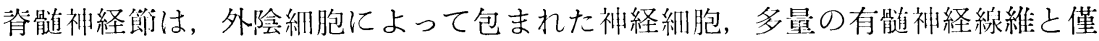
かな無髄神経線維, 結合組織及び血管等からなり, 神経線維は何れむSchwann 細胞を伴なっている.

脊髄神経節の神経細胞は, 古くから数柯の型に分類されているが, $\operatorname{Scharf}(1951$, 1957，1958）による明調細胞と暗調細胞の 2 型分類は，そのまま電子顕微鏡所見 に対しても適用し得るあのであり，既にHess（1955）は電子顕微鏡により，乙 の 2 型を明確に区別した。明調細胞は概して大型であり，Nissl 物質の量少なく， 疎に分布しているため，電子密度低く明るく見え，暗調細胞は概して小型で Nissl 物質を多量に含み密に分布するため暗く見えるあのである，光学顕微鏡によって は，両種細胞の突起の状態の相異，或は突起基部の形態による，更に橏細な分類 
が報告されているが，電子顕微鏡観察のための超薄切片は甚だしく薄いために， 突起の基部を認め得る確率が甚だしく小さく，屯し 2 個以上の突起を有する， 2 極或は多極細胞であったとしても，2 個以上の突起を同一切片上にとらえること は, 殆ど不可能に近い，彷って突起の形態による細胞の分類は，電子顕微鏡細胞 学に於いては極めて至難である。勿稐，細胞体の全形は容易に判断し得るもので あり, 小脳の Purkinje 細胞, 大脳皮質の錐体細胞の如く, 特異な形態を有するあ のは，電顕像に於いても，判定に苦しむてとは少ない，此の意味に於いて，琑䯣 神経節細胞は，両種細胞の何れもが，円形入は楕円形の切断面を示すので，おそ らく共に偽単極神経細胞であろうと想像される。前述したように，両種神経細胞 の超微細棈造は本質的な差異を有せず，単に主として Nissl 物質の量と分布の差 が認められるに過ぎないから，本報の記載に当っては，特に両型に分けることな く，各微細構造について，一括的に記述することとする。

a) 細胞核.

脊䯣神経䬦細胞の核は甚だしく大形で，極めて整然とした球形を保ち，内部の 電子密度は甚だ低い（図 1，2，3）。乙れを外套細胞の核之比較すると，神経細胞核 は直径に於いて，前者の3-4 倍に達し，核質の電子密度の差は極めて顕著であ る，正常状態の神経紐胞にあっては，核は常に紐胞の中心に位置する（図 1).

1. 核膜。核と細胞質の間には，極めて明瞭な核膜が存在して，両者を境して いる. Callan と Tomlin (1950) は, 雨棲類の卵母細胞について, 初めて 2 重構造 を有すること, 並びに外膜が有孔性であることを示し, その後多くの学者によっ て，各種の細胞について，ての事実が実証された。Afzelius (1955) Watson (1955) 等は，2重の核膜を貫く円形小孔の在存を示し，殊に Afzelius は，孔が 1 重の薄 膜によって閉鎖され，かつ小孔の周囲に高密度の管状構造が，核膜面と直角に内 外両側に突出していることを記している.

神経細胞の核膜もこれらの点に於いては例外ではない。即ち良好に固定された 標本について，核膜面に直角方向に切れた，充分に薄い切片では，核膜は明らか に2 重膜として出玩する（図 5). 小孔を認める場合には，その辺縁部で 2 重の核 膜の内外雨層は互に接着し，小孔は電子密度の高い不定形物質，又は膜状物によ ってふさがれている(図 5). ての物質が小孔縁に於いて，核膜面と直角方向に伸 び，2重の核謨の全体の厚さの，ほぼ 2 倍に達することがあり，Afzelius の示した 管状棈造即ち annulus に相当するものと思われる.

このような構造を示す高密度の物質は, 必ずし屯小孔の辺縁にのみ現われると は限らない.小孔の存在が不明瞭で, 核膜の 2 重性が明瞭な場合に, 2 重膜と重な ったように，高密度物質が存在することがある(図 5)。ただしてのような像は， 切片にある程度の厚みがあり, 小孔の近くをかすめて切れた場合には, 充分出現 の可能性が考えられる. 從って, 高密度物質が小孔と無関係に出現し得るかどう か, 明確にすることはできない。神経細胞の核膜には，この種の高密度物質が 
甚だ㕌々，かつ多数の個所に存在し，たとえ小孔が切片上に明瞭に認められない 所でも，ての物質は明瞭に認められるとと．即ち小孔が明瞭に指摘されるために は，切片が小孔の中心部近く在通る必要があるが，高密度物質在認めるととは， 小孔の过縁又はその近くを通る埸合であっても可能なととは，たとえ小孔の存在

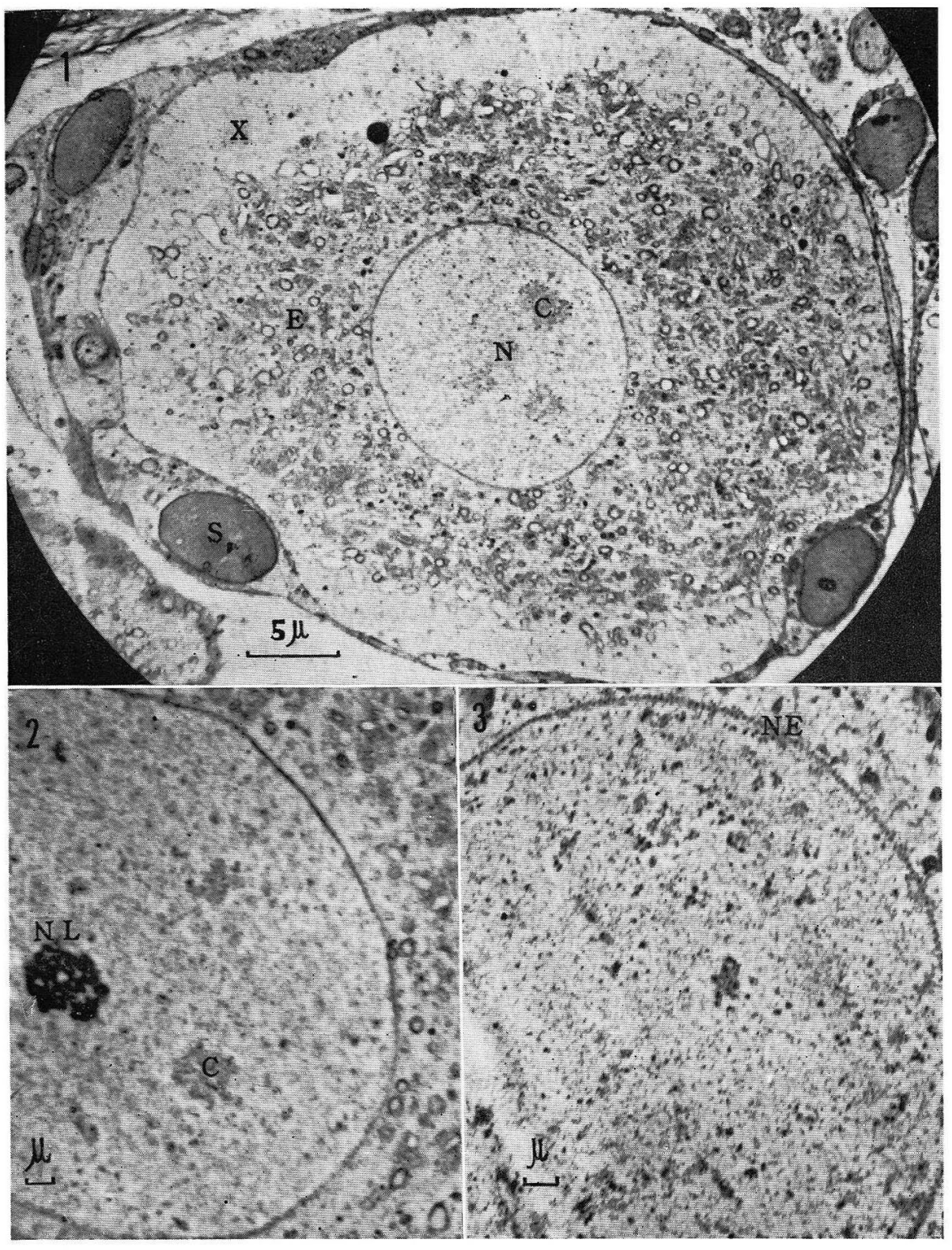


をそれ程高い頻度に発見し得ない場合でも, 神経細胞の核膜に小孔の多いととを 示す，間接の証明になるであろう。やや厚い切片を，かなり低い倍率で観察した 場合には, 屢々 2 重膜構造が不明瞭なことがあるが, 小孔と関係ある高密度の物 質は, 却って明瞭に認められ, 核膜が恰も点線のように見え, 点状の高密度物質 は，㛜密な点ではなく，杆状に見え，その長軸を核膜面と直角の方向に向けてい る。このような写真 (図 3)。に於て，一見小孔のように明るく見える核膜の部 分は, 実は 2 重膜の存在する所であり, 暗い杆状体としてみえる部分が, 実は小 孔に一致するものであることが, 高倍率の钼察をまって初めて明らかとなる.

他種細胞, 特に肝臓, 膵臓等の腺細胞に於いては, 核膜の外膜の外面に多数の 微細顆粓, 即ち Palade（19j5）によって RNA を含むとされた顆精が附着し，所 謂 rongh surfaced variety of endoplasmic reticulum（ER と略）と同一の外钼を呈 する場合が多く, 又, 外側核膜が膨出して ER 状となり, 又, ER と連結すること がある.（Watson 1954）。しかしながら, 神経細胞では, 核膜を構成する 2 重の膜 は，何れにも顆粒の附着はみられない，即ち，前述した小孔に関係ある高密度物 質の存在を除いては，核膜は常に平滑である，又， ER 状に外側核膜が膨出する 例屯見当らない（図 5). このように神経細胞の核膜が平滑であることは, 後に橏 述するように神経細胞の特徵ともいうべき Nissl 物質の構成が, 殆ど平滑な膜 から成る ER と, 分散せる RNA 顆粒とから成り, 腺細胞等の ergastoplasm (rough surfaced ER）の如く, 顆粒が膜に附着するととが稀である点と対照して, 極めて 興味ある所である。

2. 核質. 神経細胞の核質は甚だしく明るいのを特徵とする（図 1). これは chromatinの分布が柾で，含水量の高いととに原因すると思われ， chromatinの 絶対量が少ないとは考えられない. 即ち，乙のことは細胞核が非常に大形である ことと関係があり，例えば外套細胞の核に此べれば，直径に於て 4 倍大である ことは, 体績に於て 64 倍大であることになり, chromatin の絶対量が等しいと 仮定すれば，その分布密度は $1 / 64$ に疎となる。即ち，DNA を主体とする核蛋白 は甚だ疎に分散し, 電子顕微鏡で空虚に見える部分は, 電解質等の低分子化合物 を含んだ水で占められるものと思う。

一般に神経細胞の核質は，甚だ明るく空虚に見える基質内に，多数の微細粒子

Fig. 1. A survey electron micrograph of a nerve cell from the rabbit spinal ganglion. The nerve cell is completely surrounded by satellite cells. The nucleus of the nerve cell $(N)$ is conspicuously larger in size, and less in electron density than those of satellite cells $\left(S^{\prime}\right)$. Three electron-dense irregular masses $(C)$ in the karyoplasm is aggregates of chromatin, but not the nucleoli. The cytoplasm of the nerve cell may be divided into two parts, the exoplasm $(X)$ and endoplasm $(E)$.

Fig. 2. A part of the nucleus of a rabbit spinal ganglion cell. The nucleolus $(N L)$ looks like a network of high electron density. A chromatin aggregate $(C)$ is easily distinguished from the nucleolus by its lower electron density.

Fig. 3 A nucleus of the dog spinal ganglioncell. An appearance of the nuclear envelope like a dotted line may be noted. 
为分散しており，粒子は屢々珠数状に連らなって線維状をなしている（脳 4，5）。 Kurosumi 等 (1959) は，人の汗腺に於て㤥質が 2 重螺旋をなす chromonema か ら成り，これは低次の primary chromanema がコイル状に卷いて, secondary chomonema 形成すると主㖘した，吏に primary chromonemaは，約 $50 \AA$ 大の䊀子

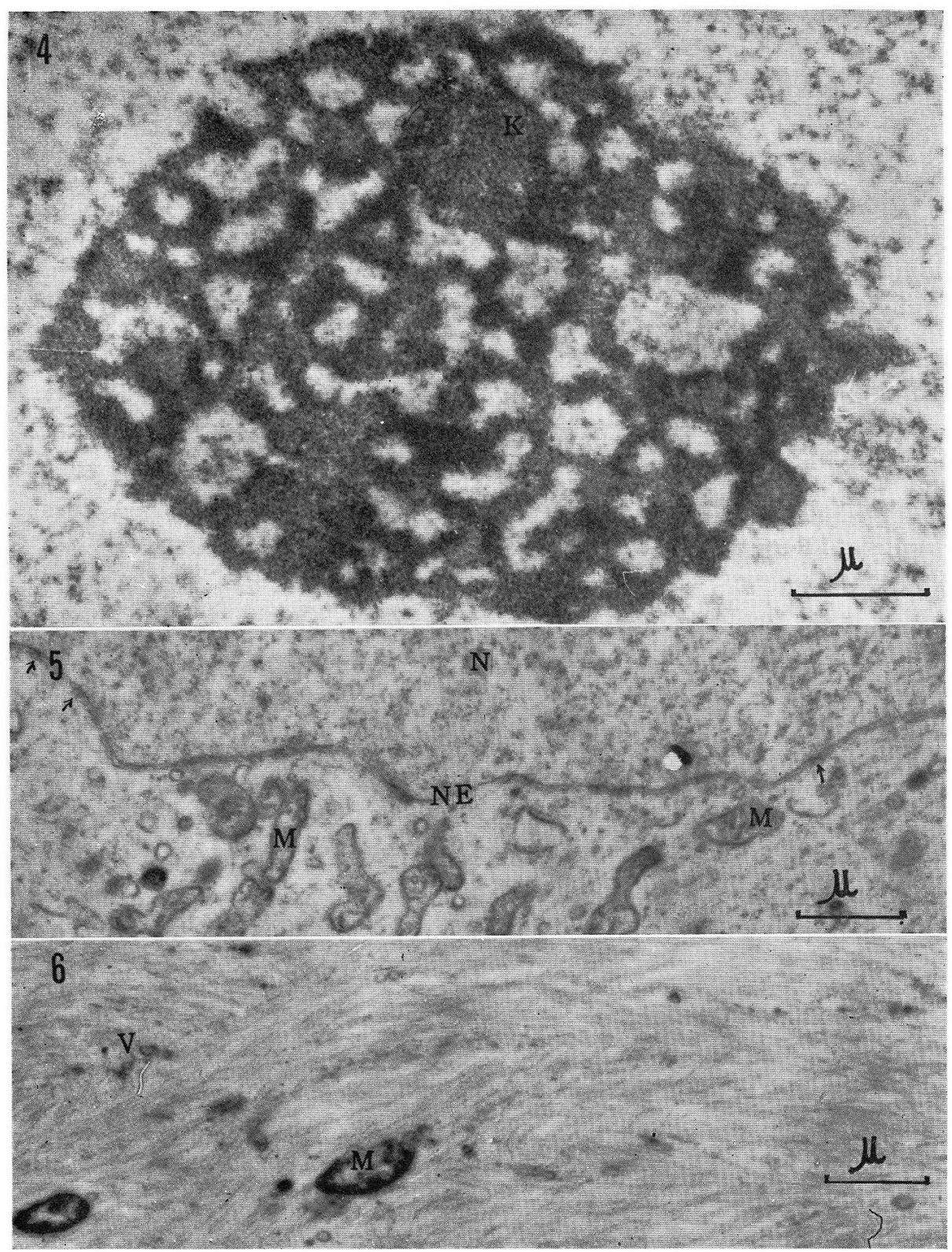


が珠数状に連らなって出来ているという。私が脊髄神経節細胞核に認めた珠数状 の線維は，大きさから判定して，Kurosumi 等の, primary chromonema に相当す るものと思われる。しかし私の例では，Kurosumi 等の主張するように， primary chromonema が密な螺旋をまいて， secondary chromonema を形成する像には，殆 ど撌しない，ただ核内に 1 -3 個のやや高密度の集塊を認めることがあり，この ような集塊の内部に於いては，明らかに secondary chromonema の存在を認める ことが出来る。（図 1，2）、又外套細胞，Schwann 氐細胞，線維第細胞等，神経細 胞以外つ細胞核核質の超微紐構造は，Kurosumi 等 (1959) が，人アポクリン汗脉 細胞で示した構造と，全く一致するから，甚だしく明るい神経細胞核の一般核質 構造（chromatin 凝集塊を除く）は，他種細胞之甚だ異った状態と考えられる．

詳細に観察すると, 神経細胞の㤥質に於ても, primary chromonemaは直線状を なさず，屡々電光状に屈折しているから，立体的にはやはり螺旋状をなすのであ ろうと思われるが，その螺旋は，通常の細胞核における secondary chromonema の ように密な螺旋ではなく, 極めてゆるくほどけた状態にあるものと思考され，乙 の意味で，他種紐胞と基本的構成に於いては差異はないが，螺旋巻きがすべて莧 だしくゆるんでいると考えられる。そのために, secondary chromonema の形成が 不明瞭となり， secondary chromonema の作る高次螺旋の形成は，ますます不明瞭 となるのであろう。しかし，そのゆるみの程度は，紃胞によって善異があり，一 般に大型明調細胞では，核の大きさも大きく，ゆるみの程度も甚だしいが，小型 觛調細胞では, secondary chromonemaの存在を川瞭に指摘し得る埸合も無いわけ ではない，乙のような神経細胞核質の特殊な構造は，分化した神経紐胞が，核分 裂を行なわないことに関係があるかもしれない。しかし，神経細胞と非常によく 似た核構造を示す卵母細胞について，黑住（1957）は同様な chromonema の形態 を報告している。卵母紐胞は一定の生長期を経た後には，成熟分裂を行なうもの であり，てのような核樍造に原因して，分裂能力が失なわれるとはいえないであ ろう.

核質一般に反し，核内の所々に集塊を示す染色質（図1）は，明らかな 2 重螺旋 構造を示し, Kurosumi (1958), Amano (1956) の示した分裂時染色体の構造に類

Fig. 4. The nucleolus of a rabbit spinal ganglion cell. Nucleolonemata consist of thin filaments which seem to be arranged in parallel rows transversally or obliquely to the long axis of the nucleolonema. It is likely that the thin filaments may be twisted helically. In node-like portions $(K)$, the direction of thin filaments is altered at constant intervals. The substance filling the meshes of the nucleolus seems to be continuous to the matrix of karyoplasm.

Fig. 5. The nuclear envelope $(N E)$ of a rabbit spinal ganglion cell. Upper part of the picture indicates the karyoplasm $(N)$, while below the cytoplasm containing mitochondria $(M)$. Double structure and pores (arrows) of the nuclear envelope are apparently seen.

Fig. 6. A part of the axon of a myelinated nerve fiber found in the rabbit spinal ganglion. Neurofilaments form bundles which are probably twisted each other. Mitochondria $(M)$ and vesicle-shaped endoplasmic reticula $(V)$ are observed. 
似する. 従って, てのような染色質集塊は, heteropycnosis をおこした染色体 (Barr の所謂性染色質）ではないかと思われる。大屋（1959）は，人の唪䯣神経節細胞 の光学顕微観察に於いて，核質内にエオジンに好染する球状又は不整形小斑を発 見し，Feulgen 陰性であるから，染色質ではないとしている，電子顕微鏡でみら れる集塊は，一見大屋のエオジン好性小斑に類似するが，その内部に明らかに chromonema の重複螺旋構造が確認され，かつその 1 部は，集塊外の一般㤥質に 散在する chromonema の 1 端に直接連結する像が認められるから，両者は全く别 個の存在であろうと思われる（図 2),

3. 核小体. 神経細胞は著明に大型の核小体を有し, 極めて明瞭な糸球状の紐 状物から成ることは, 既にわれわれが報告した所である（黒住と秋山, 1958).この 絓状物は Estable と Sotelo（1951）により，鍍銀標本の光学顕微鏡的観察に基いて 発見された ‘nucleolonema'に一致する。春能道神経䬦細胞では，大多数の核小体が nucleolonemaの立体的網工加ら成り, 全体として整然とまとまった球形, 又は譛円 形をなし，核質との間には特別の限界膜は存在しない（図 2,4). しかし核質に対 して，弥漫性に移行する像も認められない，通常，核小体は核の中心部附近に存 在し，核膜に直接揢する像は認められず，又前述した染色質塊と，特別の位置的 関係を示すこともない（四 2). Nucleolonema の電子密度は甚だ高く，染色質塊之 は容易に区別することが出来る。低倍率の峴察では，nucleolonemaは䨢々均質性 の暗い紐状物として認められるに過ぎないが，やや高い倍率の微祭によって，乙 れが約 $100 \AA$ 前後の顆䊀から成り，顆粓の連結によって生じた線維状物が互に全 行に, 多くは nucleolonema の長軸に対して, 斜に配列している（図 4). このよう な平行配列は，既に Palay と Palade（1955）が神経細胞で認めており，田中 （1957）はリンパ芽球について，黒住と秋山（1958）はウサギ卵巣の卵胞上皮紬胞 に於いて，螺旋状構造ではないかと暗示した。次いで Yasuzumi 等 (1958) は同 様に各種細胞の核小体の nucleolonemaに螺旋構造があるとし, Porter (1954), Bernhard 等 (1955). Palay と Palade（1955）及び吾々（黒住と秋山 1958）が指 摘した顆粘状物が，真の顆粒ではなく，螺旋の山であると諭じた。

Kurosumi 等 (1959) は次いで人のアポクリン汗腺絸胞核に於いて, nucleolonema が更に低次の珠数状糸の螺旋巻きから成ると述へ，後者を primary nucleolonema とし，乙れに対して Estable と Sotelo (1956) 以来くり这して述べられてい る光顕可視の nucleolonemaを secondary nucleonema と呼んだ。しかしこの secondary nucleolonema がや室螺旋であるか，充実螺旋であるか，或はほぼ何本の紐糸 から成っているか明膫にされていない。私は，脊能神経郎細胞の核小体について， primary nucleolonema の走行を詳細に检討した所, Kurosumi 等（1959）により, 汗腺細胞等の chromonema で示されたような中窒螺旋を暗示する像, 即ち輸状の 横断面, 又は中軸に裂隙を有する縦断面には, 一度も遭遇しなかった。更に secondary nucleolonema の横断面と思われる円形部の内部には, 点状顆粘が密集して 
見られ，維断面には，斜走する多数の平行線維，即ち primary nucleolonema が存 し，その secondary nucleolonema の長軸に対する傾斜度は，部位によって異る (図 4).

そこで私は nucleolonema は chromonema と異り，中空螺旋ではなく，少なくと む 10 本以上の primary nucleolonemaの束から成り，強く縄をよったような螺旋 走行を呈しているものと想像する。即ち nucleolonema は中空ではなく，充実性の 螺旋束であると思われる，更にウサギの春䯑道神経䬣細胞では， secondary nucleolonema の処々に，乙れと同一の電子密度の結䬣状，又は球状の塊が附着している ことがある(図 4)。乙の部分の内部に於ける primary nucleolonema の走行は特異 的で，一定の幅をもって走行が急に変っており，その立体構造は，ちょうどゴム 紐の束を放じって縄状となし，急に張力をゆるめると生ずる絬測の形に似てい る。

Nucleolonema は頻繁に分枝吻合して網工を作るが，吻合すれば太くなり，分枝 すれば明らかに紐くなるから，任意の部位における 1 本の secondary nucleolonema を構成する Primary nucleolonema の数には变動があると思われる。しかし10本 以下之思われる像は得られない。又，個々の primary nucleolonemaの長さはわか らない,

Nucleolonema の構成基本単位たる 100一150 丸 大の粒子は，後述する Nissl 物 質の領域に打ける高密度䊀子と大きさに於いて，又，電于密度に於いて相等しい， この種の細胞質内精子は，Palade（1955). Palade とSiekevitz（1956）によって, RNA を多量に含有することが, 生化学的に確められている。核小体は組織化学的 に RNA を有するととが明らかであるが，おそらく nucleolonema を構成する微綝 料子は，RNA を豊富に含有するのではあるまいか. Nucleolonema の網眼を占め る物質は甚だ明るく，㤥質一般と殆んぞ同一の電子密度を有す（図 4)，その物質 が㤥質の基質と全く同一の物質で，chromonema と nucleolonema の共通の媒質を なすものであるか，或いは単に見かけ上，同質に認められるに過ぎないのか，末 だ充分に明らかではない.

大屋（1959）は人の㝓䯑道神経節細胞に於いて屢々核小体内部に，大小の多数の 空胞が出見し，核小体の表面から凸隆し，遂に核小体から分難して核質中に放出 されることを，光学顕微鏡により認めた。同種の钼綉は，古くから Rohde (1903)， Marinesco (1905)，Körner (1937) 等によって報告されている。大屋によれば，核 質内に出た空胞は，エオジンに好染する小斑に変ずるといい，電子顕微鏡によっ て認められる nucleolonema の網眼が，光学顕微鏡で見られる核小体内部の空胞 に一致するのであろうという。後者の論議は一忘措いて，前述のエオジン好性の 小斑なるものが，私がここに観察した核質内の電子密度の，やや高い集塊にもし あ一致するならば，その構造と電子密度の類似性を，核小体に求めることはでき ない，おそらくエオジン好性小斑と私の觀察例の核質内集塊とは，全く別個のも 
のであろう。

Nucleolonema の網眼を占める物質と核質の基質は, 電子密度の点に於いて, 殆 んど美を認め得ないから, 両者の移行を想像することは難くない. しかし前者 が明瞭な膜を以て包まれた空胞を形成し，乙れが核小体表面に膨出し，遂に分難 するというような光顕所見を寒きする何等の所見も得られなかった。核小体の 表面はもとより，空胞に擬せられる網眼の表面にも全く膜は存在しない. Körner （1937）は核小体から顆粒が出芽して，核質内へ紋断される所見があるという. 前述したように， nucleolonema の処々に結䬦様の物体が生ずることがあること， これが時として核小体の表面に凸隆することは, 今回の脊䯑道神経節細胞の観察に よって明らかにし得た。しかし，てれが分難紋断されるという明確な像は，少な くとも䏹在までには, 神経紏胞では発見されなかった。ただし，黒住と秋山 (1958) が先に報告したウサギの卵母細胞では，乙れに類似する睍象を多く発見し，紋断 されたような滴状構造を pars sphaeroidea と呼んだ。神経細胞の nucleolonema 結 即む, 時として球状を呈して, pars sphaeroidea に類似することもある.乙のもの

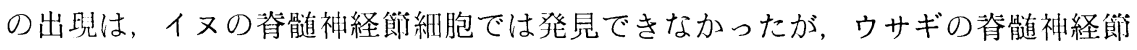
細胞之小脳皮質 Purkinje 細胞では俴々認めた。この構造が nucleolonema の螺旋 ねじれが特に強くなった所に生ずるであろうことは前に論じたが，乙の部分が何 等かの原因で分難することもあり得べきととと思われる。

b) 練胞質.

脊髄神経創細胞の細胞質は, 大型明調細胞に於いても, 小型暗調絸胞に於いて 屯, 何れ屯内, 外 2 部に明瞭に区別される。外層即ち外形質 (ectoplasm) は細胞 の周辺部を占める. 極めて電子密度の低い带状部で, Nissl 物質, Golgi 装置を含 まず，内方の内形質 (endoplasm) と明瞭に区別されることが多い（図 1). 外形質 の幅は，大型明調細胞の方が，小型暗調細胞に比べで潘かに原く，雨形質間の境 界む一段と明瞭である。，小型暗調緗胞に於いては，時として外形質の存在が全く 不明な渮合もある。尚小脳 Purkinje 紐胞，大脳皮質神経細胞等に於いては，外形 質の在存を認め得ない.

外形質が明調に認められるのは，この部に Nissl 物質を久くためであり，Golgi 装置も認められないが，Golgi vesicleに似た小空胞が散在性に存することがあ る。糸粒体は少数認められる。神経微原線維（neurofilaments）毛存在する。

1. Nissl 物質. Nissl 物質は, 光学顕微鏡所見に於いては, 不定型の大小の顆 粘状物として, 塩基性色素に好染して認められるので屢々 Nissl 小体，又は Nissl 顆粒とも呼ばれている。しかし，電子顕微鏡所見に於いては，乙れは糸粒体の如 く限界膜を有して, 明瞭な境界を示すことはなく, その境界は不鮮明で, 大きさも 形状も，極めて不規則である．従って「小体」と呼ぶよりも，むしろ「Nissl 物質」 と称する方が妥当であるように思われる（図 7).

Nissl 物質は, チオニン, トルイジンブルーその他の塩基性色菜に好染し, 塩 
酸加水分解， ribonuclease 消化等によって，染色性を失なうことから， RNA を主 成分とする物質であることが知られている。このように細胞質に存する RNA 含 有物質は，神経細胞以外の細胞，特に腺細胞や形質細胞等に豊富に含有され， ergastoplasm の名で呼ばれており，その構造は，薄膜により境された胞状体の外 面に，1層に微細顆粒。の付着した所謂 endoplasmic reticulum（REと略）の rough surfaced variety (Palade 1956) 或は, Sjöstrand (1955)の $\boldsymbol{\alpha}$-cytomembrane とよ ばれるものに一致するとされている。

Nissl 物質の電子顕微鏡的䚋察は, 既に, Hess (1955), Palay 之 Palade (1955) Honjin（1956）等によって報告され，彼等は何れも，Nissl 物質が rough surfaced の ER に他ならぬとしている。しかしながら、私の観察によると、Nissl 物質の 棈成要素は ergastoplasm（rough surfaced ER）と異ならず，微紐顆䊉と薄膜より 成る胞状体とから成るが, 顆粘之胞状体之の位置的圆係, 即ち配列状態に於いて, Nissl 物質と腺細胞等の ergastoplasm とは甚だしく異っているととが発見された.

即ち, Nissl 物質の領域には, 直径 $150 \AA$ 前後の電子密度の高い微絒晫粘が数 個㱜集団して小塊をなし，乙の小塊が細胞質基質内に分散している。乙れと混じ て, 明らかに endoplasmic reticulum に属すると思われる胞状物が認められ，時と して扁平化した胞状体が数個平行に配列して，層板状構造を見出することあある が, その膜面は平滑で, 所謂 rough surfaced ER の如く, 微細顆粘が 1 層に付着 するようなととはない（図 8，9）.

Nissl 物質巾に出現する小塊状の顆䊀は, その大きさと電子密度より, Palade (1955). Palade と Siekevilz (1956) 等が，RNA を皚富に含むものとして記諓し た晫䊀に一致し，黑住（1957）の solid microsome 之同一物之思われる。しかし，黑 住がウ二卵で記載したような孤立分散するもの，或は珠数状に速鎖するようなも のは認められず，常に小集时をなして群集するてとを特微とする。乙の小塊の形

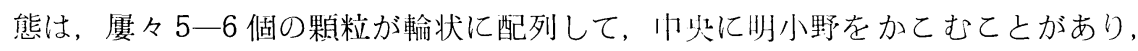
又その中心に 1-2 個の顆粒を有して，梅鉢状，或はロゼット状をなすものもあ る。しかし，不整多解形の集団をなす埸合も認められる（図 8). Palay と Palade （1956） あ亦, この種顆粒のこのような配列状態を钼察しているが, 彼等はこれ を二次元的に考えて，rough surfaced ER の膜面の平面視，或は切線断面之見な し， RNA 顆䊀が ER の膜面上に，輸状入はロゼット状をなして付着するあのと 考えた。しかし，私の観察では，Nissl物質における ERは，大部分表面に顆䊑を 付着せしめず，稀に付着する所を認める茘合でも，粕䊀は単離して付着すること なく，必ず小塊をなしたまま膜に接着している（図 8). 徒って ER 膜の切線断面 に於いても，その部分には顆粘を認めるてとなく，中等度の電子密度をむって均 質性に見える。乙の点，黑住等（1959）によって報告された膵腺細胞の ER 膜の 切線断面像とは明らかに異る。

然らば RNA 顆粘の小塊は，立体的に如何なる形態を有するものか。 この問題 
は，極めて薄い（100 A 以下）連続切片を作製しなければ，正確なととは決定し 得ない。しかし，乙れは技衍的に非常に困難であるので, 多数の切片像より, 立体 構造を推察する以外方法はない，極めて屡々，㡏状の断面が得られるこよから 考えれば，中空の球状唒列をなす可能㨫が考えら机る。乙の場合，切片が球の川

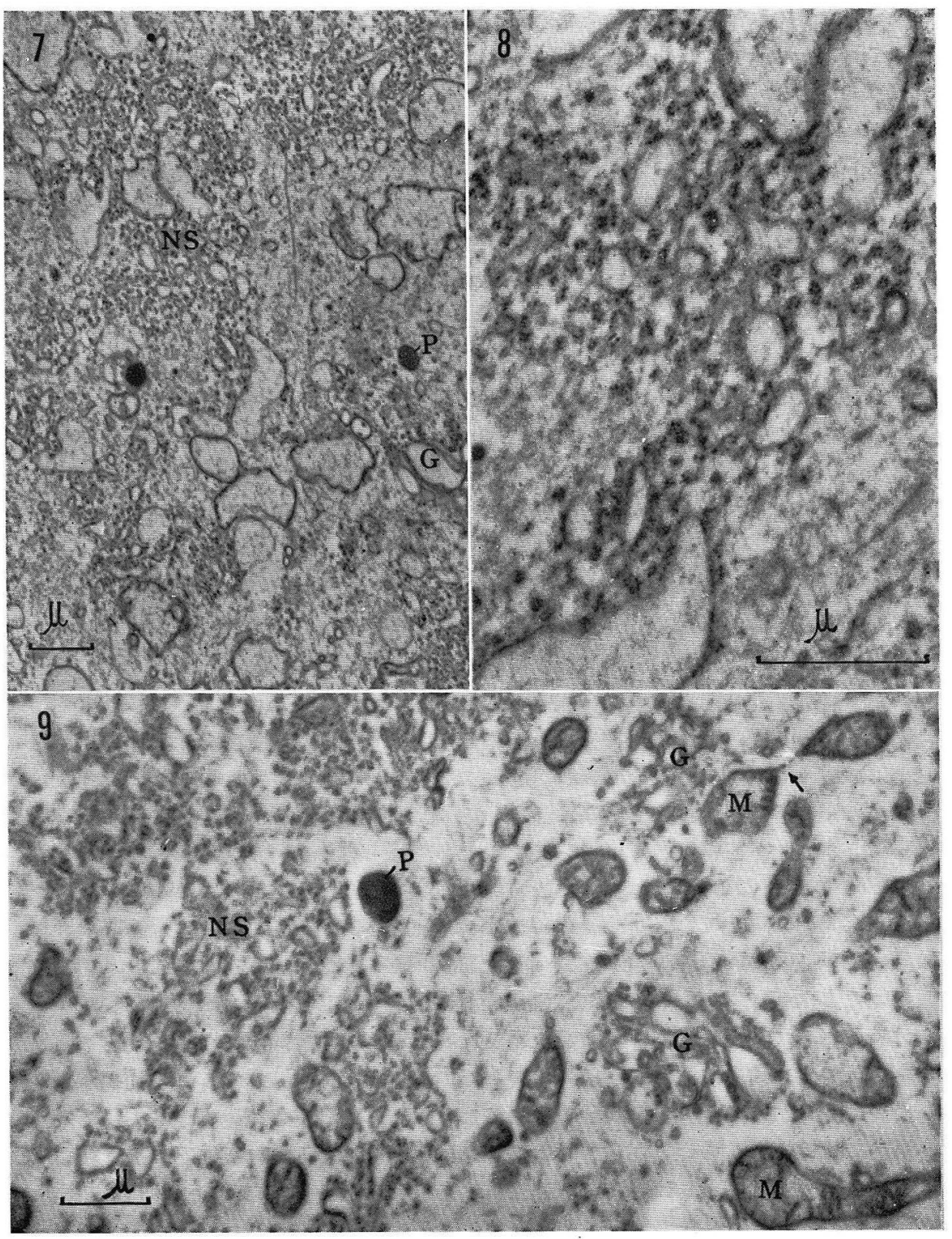


心を通る場合には輪状に現われるけれども，もし切片の厚みの中に球の半分が含 まれる（椀状）ような場合には，電子顕微鏡の焦点深度が非常に深いととから考 えて，像にはロゼット形が現出することが当然可能である，切片の原さとの小塊 の切れ方によっては，実物が球形の集団であって屯，不整多角形の像を表わすて と屯亦可能である，從って，実察に顆粒が種々な形の塊を作ることを仮定する必 要なく，極めて整然とした球形の集団でも，切れ方，切片の原み如何によっては， 程々な不整形の像が得られることを強調したい。おそらく，1個の小塊を形成す 万顆粘の数は 10 数個で, 球の表面に並んだように配列するのではないかと考え られる。

これを要するに Nissl 物質では, 三次元的な小塊をなす微細胞顆粒が, 細胞質 基質やに分散し，そのある屯のが，そのまま ER の膜面に挍着するとと屯ある のであって，Nissl 物質は， smooth surfaced ER，或は極端に顆䊑の少ない rough surfaced ER と，小塊を作る RNA 顆精との混合であると見なされ，普通の意味 の rough surfaced ER ではない.むしろ smooth surfaced ER と rough surfaced ER の中間的存在と屯考えられる。

このような小塊状の RNA 顆粓は，幼若な細胞，例えば胎児の膵腺細胞（Mun-

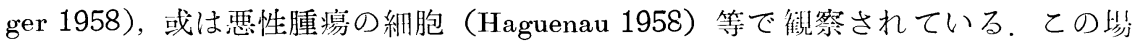
合多くは ER の胞状体を殆ど伴っていないが，顆粒の记列状態は，私がこてで報 告した Nissl 物質の場合と全く同一である，即ち Nissl 物質は，rough surfaced ER の未分化な状態と考えることができるのではあるまいか。他方，このような特異 な ER の形は，死後時間の延長，或は周定不良に基づく人工産物ではないかとい う疑問があげられる。しかし全く同一の手技を以て网定作製した腺練胞では，乙 のような特徴は認められず, RNA 顆粒は整然と膜面に一層付着していること, 又 死後変化を防ぐ意味を以て，試みに動脈内に Os $\mathrm{O}_{4}$ 液を注入して困定した啰合に も，同様の像が出現すること，更に膜面に付着していた顆粒が，人て的或は死後 変化によりはがれて，しかる後凝集したものであれば，前述したように整然たる 球形に凝集することは，おそらくないであろうし，又一部には剝れないで一層に

Fig. 7. A part of the endoplasm of the rabbit spinal ganglion cell. A mixture of clustered small granules and large vacuoles is NISSL substance $(N S)$ which occupies most of the field. Parts of the GOLGI apparatus $(G)$ are seen at the right hand side, and a dark granule labelled $P$ may be correspond the pigment granule.

Fig. 8. A higher magnification view of the NISSL substance. Small granules forms round or irregular clusters, most of which are scattered freely in the cytoplasm; but few of them are attached on the surface of vacuoles.

Fig. 9. A part of the cytoplasm of a dog spinal ganglion cell. The difference between the NISSL substance $(N S)$ and the GOLGI apparatus $(G)$ is evident. In the latter are observed tubular GOLGI vacuoles arrangd in a network and small vesicles aligned ina row like a string of beads. Mitochondria $(M)$ possess marked cristae mitochondriales, and some of them show a probable feature of splitting as indicated by an arrow. A dark round granule $(P)$ is the pigment. Small delicate filaments (neurofilaments) run in all directions within the clear cytoplasmic matrix. 
付着して残っている顆粒が見えてあよいであろう。私は Nissl 物質におけるての ような特異な顆精配列，及び顆粒と膜との関係を，人工産物であるとは考えない． しかし一歩を襄って，たとえ多少の人工的影響を蒙っていると仮定しても，同一 操作によって, かくも異った像を呈出するという点に於て, Nissl 物質は腺細胞 等の ergastoplasm とは明らかに異った性質を有することは立諌出来るし，乙れ が Nissl 物質の特徵であると称するに，ちゅうちょしないであろう。極く最近, Smith (1959)は, トカゲ (Phrynosoma cornutun) の交感神経節絒胞に於て, Nissl 物質を 2 型に分類して, 䊶胞の深部に存在するものを 'reticular Nissl body' と称 し, 從来 Palayと Palade (1955) その他によって報告されたものと, 基本的に一 致するものであり，乙机対して紏胞の袁面に存するあのは'areticular Nissl body’と呼ばれ，乙れは ER に属する膜構造を全く含まず，RNAを有する，や や大きな顆精の分散により成立っていることを示した，被はトカゲの reticular type が Palay と Palade (1955) その他の報告した所よりも, 顆粒の膜面への付着 が少いとと， $\mathrm{ER}$ が大部分胞状をなして疎に存すること等を指摘し，私の推察に 近似する点が多い. 又私が本論文で前述したような, RNA 顆精の小塊は, reticular と areticularの移行部に見られると述べている.

私の钼察したような哺乳類の神経絸胞では, Smith の指摘するような, 2 程の Nissl 物質を区别するととはできない，私の例は, Palay と Palade (1955) 等の記 戴より屯, むしろ彼の reticular type に類似する点が多く, かつ 2 型の Nissl 物 質の移行部の所晃に最も近い。乙の事実は，Nissl 物質が從来の研究者のいうよ うに，単純な rough surfaced ER に属するものと，簡単に決定できない特性を有 していることを，明らかに示したものである。

尚このように核小体と Nissl 物質の超微細構造は全く異なるから，核小体がそ のまま核外に脱出して，Nissl 物質になるとは考えられない。毛しもそのような ことが起るならば，顆粓配列の組み変えが起らなければならない.

2. Golgi 装置. 神経細胞は Golgi (1898) が初めて内網装置 (Golgi 装置)を発 見した紐胞で, 他種細胞に比べて, 格段によく焱達した Golgi 装置を有すること が知られている。しかしながら, 從来ともするとGolgi 装置は生態時には存在せ ず，鍍銀，才スミウム鍍黒等によって人工的に見わされた像であるとする説が横 行した (Parat 1924, Ries 1935, Baker 1944, Palade とClaude 1949). しかし電 子顕微鏡によって, Golgi 装置の実態が明らかにされる（Dalton と Felix 1953， 1954, Sjöstrand と Hanzon 1954）に及んで，てれらの説は殆んど主張されなくな った。 精神絸胞については, Palay と Palade (1955) が種々の精神細胞に於て, Nissl 物質と異万平滑膜で作られた網状構造があるとして, agranular reticulum と名付け，次いで Honjin（1956）が，乙の構造と古典的 Golgi 装置が同一物なる ことを，鍍銀標本の電了顕微鏡観察によって明らかにして，それ以前に知られ ていた上皮細胞の Golgi 装置（Dalton と Felix 1954，Sjöstrand と Hanzon 1954， 
Haguenau と Bernhard 1955）と, 根本的に一致することが知られるに至つた.

私の钼察結果は，彷来発表された Golgi 装置に関する電子顕微鏡所兒と概水一 致するが, 尚特殊な形態にむ遭遇した。 即ち, 一般に Golgi 装置は平滑な膜で包 まれた大小の胞状体より成る。乙の点 Nissl 物質中に出梘する胞状体に類似する が，Golgi 装置内部には，Nissl 物質に存するような RNA 敤粘の小塊は全く認め られない，その代りに，Golgi 装置には直径 300-500 ^ の小胞 (Golgi vesicle) が 心ず存在する。 Golgi 小胞よりも大きな球形, 或はやや絒長い胞状体, 即ち, Golgi 大胞 (Golgi vacuole) が存在するととあある. 又大胞が数個立列して, 恰む庄迫 されたように扁平化し，所謂 Golgi 層板（Golgi lamellae）を作るとともある（図 9，11，12）。しかし Golgi 大胞と Golgi 層板は，すべての Golgi 装置の断面に見 れるとは限らない，乙れに反し Golgi 小胞はすべての部位に出見し，甚だしきは Golgi 小胞のみの集団として認められる㭶合もある(図 9). ただし, 電子顕徵鏡 的観察に用いられる㽖片は甚だしく薄いために，ちょうど Golgi 小胞の部分のみ を通じて切られた切片であり，切片に現れなかった Golgi 装置の続きには，曆板 或は大胞が存在するのかむしれない.

Golgi 装置はその周辺に於て, Nissl 物質と入り混ざり, 両者の閒に明瞭な境界 を設けることが困難であるばかりでなく，Golgi 大胞之Nissl 物質ゆの胞状体と の区別が困難であるてとああり，所によって両者の直挍連絬も認められる（図 12)，從って Golgi 装置という名称よりあ，Golgi 物質とよんだ方が適切であるよ うに思われる所がある。

Golgi 大胞は時として管状をなし，互に網目状に吻合することがあり，ての点 は Nissl 物質の胞状体と著しく異った傾向である（図 9). 又時として, Golgi 大 胞が朋らかな 2 重の同心侧をなすことがあり，その内部に少数の Golgi 小胞を入 れていることもある(図 9)。乙のような像は, Golgi 大胞が陥入 (invaginate) 寸 るために生ずる像ではないかと思われる。

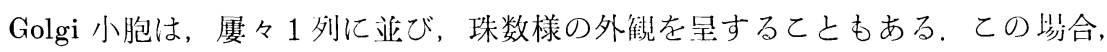
隣揬する小胞がやや離れていることが多いが，時としては隣揬する小胞が互に密 着していること屯あり，小胞の融合により，管状の大胞が形成されるのではない かと疑われる像もある（図 9)，又その逆，即ち大胞の寸断による小胞の形成も 当然考えられる。後者の機序は，Grassé と Carasso (1957)によって主辳された。 彼は Golgi 大胞は, Gogi 装置の二次的要素で, Golgi 層板がその基本的要素であ ること. Golgi 小胞は, 層板の端がち切れることによって成立することを唱えた。 しかし神経絒胞では, Gollgi 小胞はすべての切片の Golgi 装置の部分に認められ るけれども, 層板, 大胞は，乙れを欠くことがあること，䨢々特異的な網状紃管か ら成る Golgi 装置を見ること, 後者に揬触して, 每常 Golgi 小胞が見られ, 更に Golgi 小胞の珠数状配列が顕著なとと等が認められ，おそらくGolgi 装置の基本 的構造は Golgi 小胞であり，乙れの膨大により大胞を作り，相互融合によって網 
状の縕管が形成されるのではあるまいかと思考される。

Chon 上 Meek (1958) 忠, カタッムリ（Helix aspera）の神経絒胞について, 3 秹 の脂質顆䊀を認め，その1つである 'blue granule” は卵円形の物体で，その周辺 部に同心円状に走る層板構造が喼められることを示した。彼等は calcium-osmium

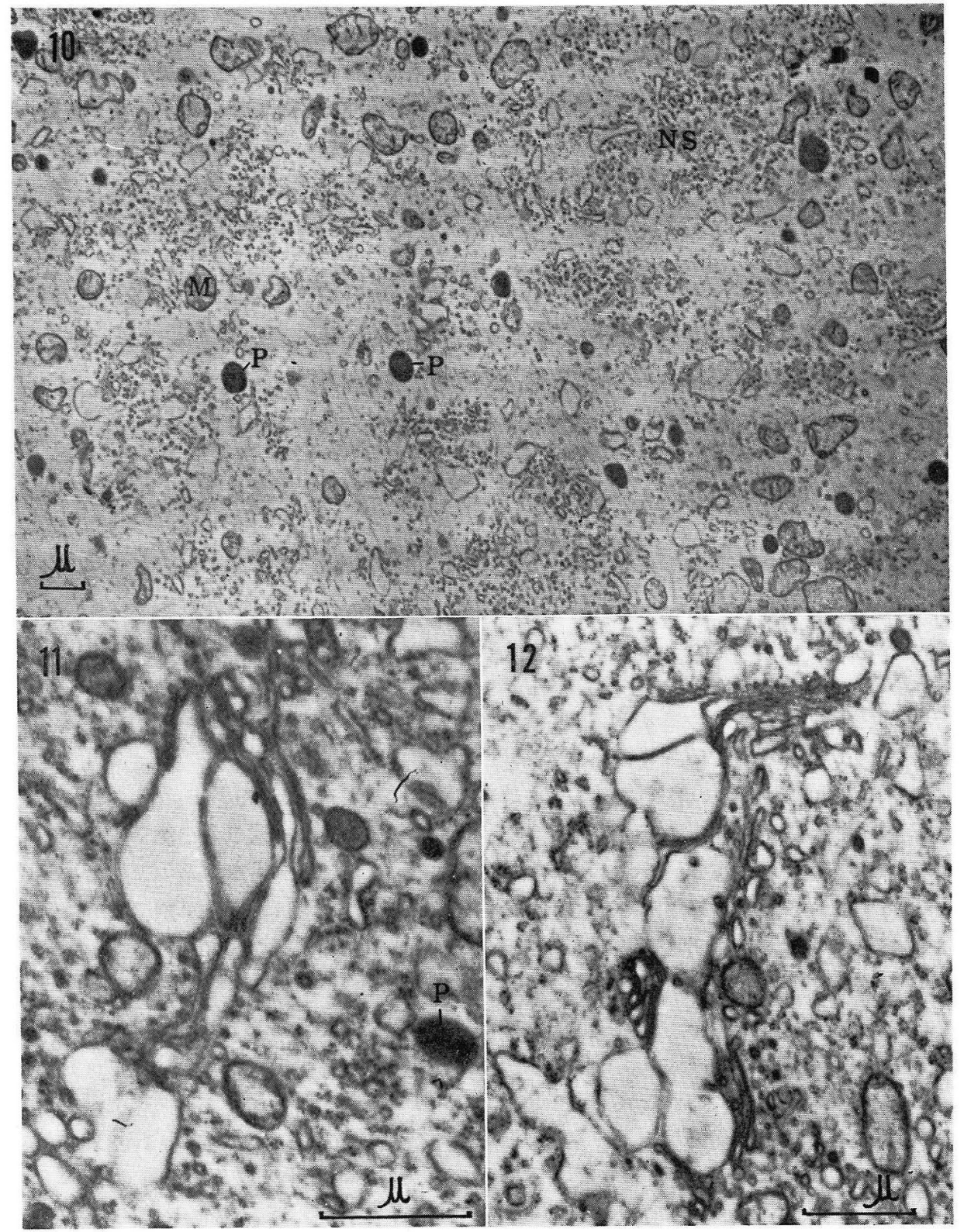


周定による時は，乙の構造がよく保持されるが，通常の osmium 周定では，この 物体が崩壊して，周囲の層板は直線状にのびて，所謂 ‘Golgi’ 装置の像を呈する ことから，Golgi 装置は人工産物であろうとしている。しかし彼等の説明による と，私が本文に述べたような網状の Golgi 装置の成立は語明されない．私はこの 点に於ても，Chou とMeek（1958）の説に賛意を表するととはできない.

3. 糸粘体. 電子顕微鏡的に糸粓体は，2重の外膜之 2 重膜より成る内部稜 (internal ridge, cristae mitochondriales) を有することによって, 容易に同定し得 る（Palade 1952）（図 9)。神経節紐胞の糸粒体は極めて多様性で，屢々不整形を なすが，概ね球形梏円形又は短桿状である（図 10)。乙れに対して, 軸索内部の 糸粒体には，極めて長い糸状の糸粒体を認めるてともある．時として糸粒体が甚 だしく脵大し，内部が明るく見えることがあるが，乙れは人工的变形である可能 性が大きい. Cristae mitochondriales は, 外周の 2 重膜の内面から, ほぼ直角の方 向へ内腔に突出する。從ってやや長い桿状糸粒体に於ては, cristae は互に平行 に糸粒体長軸に直角方向に並んで, Palade (1952) の最初の記載や, Sjostrand (1953), Sjöstrand とRhodin (1953) の報告した所に類似する（図 9). しかしての ような糸粒体の 1 端や, 短桿状乃至球形の糸粒体に於ては, 外膜が円く彎曲する ため，乙れよりほぼ直角に突出する cristae は全体として放射状の形態を示すこ とになる。このような cristae は，おそらく2 重膜の稜状構造ではなく，管状の 突起であると思われる. Beltと Pease（1956）はこのような cristae microvilli 様とよんだ。神経細胞の糸粒体の cristae も大部分はこの様な形態を有するもの であると思われる，何故ならば，屢々管状の cristae の横断面之思われる小輪状 の構造が，糸粒体内部に認められるからである（図 9).

糸粒体は Nissl 物質の内部に埋って発見されることもあり，又 Nissl 物質と何 等関係なく細胞質基質中に分散して存することもある。屡々特異な形態として, 糸粒体が覀鈴状をなし，又2個の糸粒体が鋭い尖端を以て相向い，その間に糸状 の連絡があることがある（図9）。乙の像は恰も餅をちぎったように見え，乙の荆 合，互に向いあう面の糸精体外膜がかなり明瞭に見れているので，波状にうねっ た糸粒体が，功って切れたための像と考えるよりは，糸粒体の分裂像と考えた い. 後通するように, 神経絊胞には相当量の色素顆䊀が存し, かつ糸粒体が色素 顆粒の起原ではないかと思われるので，もしての考えが正しいならば，糸料体は その色素顆䊚への転化のために生ずる減数を, 分裂によって補うことああり得べ きととと考えられる。事実, 糸粒体の分裂と思われるような像は, 色素顆粒の多 い盎䯣神経朗紏胞に多く認められるようである。

Fig. 10. A spinal ganglion cell of the dog. Various shaped mitochondria $(M)$ and masses of NISSL substance $\left(N S^{\top}\right)$ are scattered. Among them neurofilaments extend in all directions. Dark granules $(P)$ are pigment granules.

Figs. 11 and 12. GOLGI apparatus from spinal ganglion cells of the rabbit. These are composed of small vesicles, lamellae and large vacuoles. $P$ indicates a pigment granule. 
4. 色素顆粒。神経組胞の紐胞質中には，極めて霊々，非常に電子密度の高い

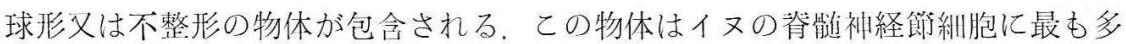
く認められ，人の大脳皮質神経絒胞がこれに次ぎ，ウサギの神経絸胞では僅かに 認められる（図 9，10，13～15）。このような物体を，Palayと Palade (1955）は

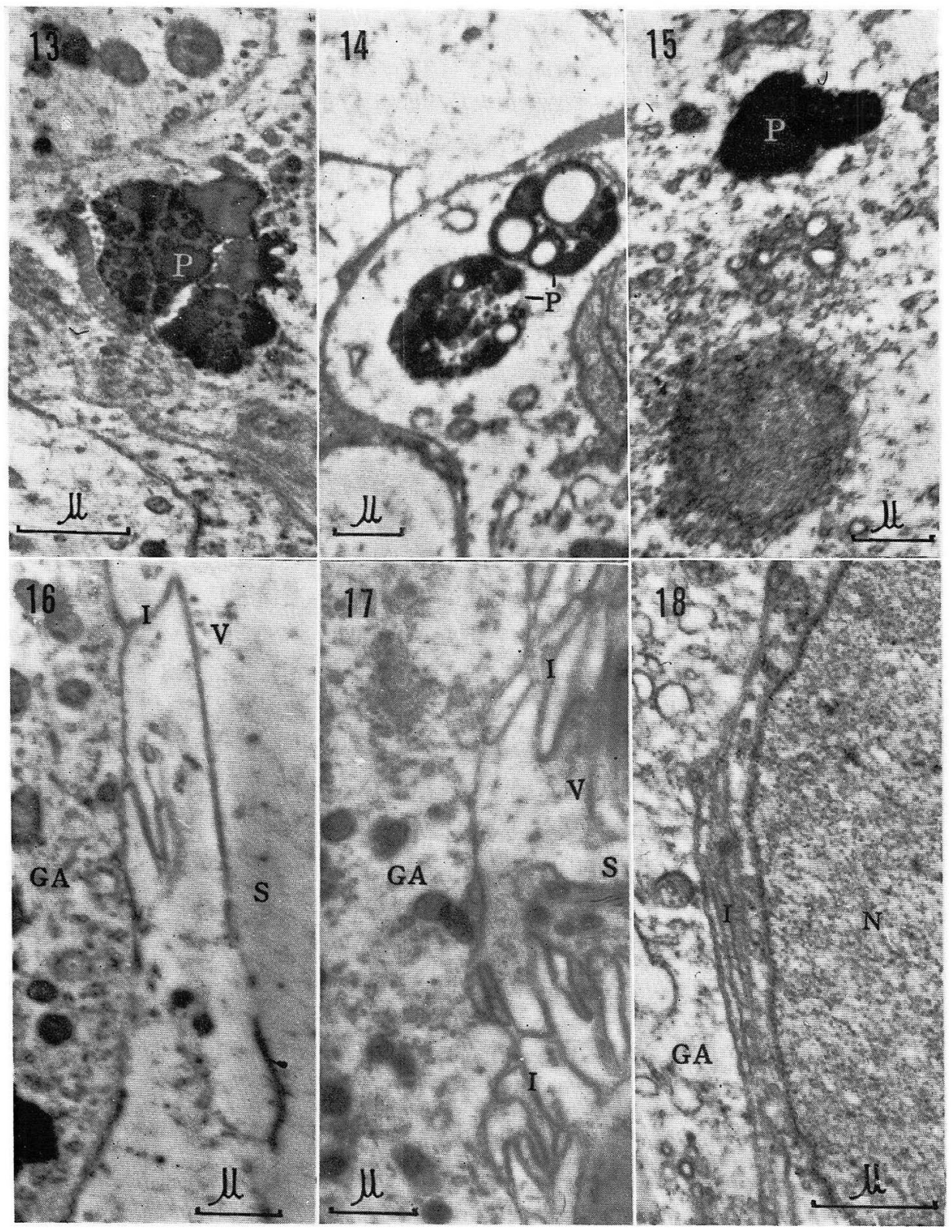


dense inclusion と呼んでいるが, 出現の頻度と形態, 電子密度等より推察して, 色 素顆精に相当するものであろうと考えられる.

この顆粒は多くの豩合, 椣めて電子密度の高い筒円形の顆粒であつて, 細胞質 中に分散して扣り，大きさは糸粒体よりやや小さいかほぼ同大であって，極めて， 微小なものは見当らない，内容は一様に密度大な壦合もあるが，曹々更に大なる 電子密度の小顆粒が数個含まれることがあり，又稀に明るい空胞状のものを含ん でいることもある(図 10).

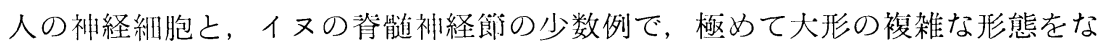
す色素顆精が発見された（図 13-15）。乙れは多数の不規則形の大小さまざまな, 湳状乃至顆粘状の物体が集合して，大形の塊を作ったものであり，塊を構成する

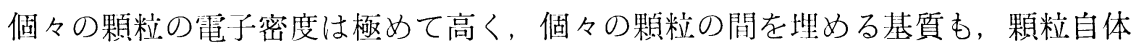
の密度よりも低いが，かなり高い電子密度を有する（図 13）。人の神経紐胞の 1 例では, 塊をなす色素顆粓の中，2-3のものが空胞化し，完全に空虚な球状内容 を，暗い物質が輪状に职り用んでいる（図 14）。このような空胞を含む色素顆精 は, Hess (1955) によって, 電顕的に, 大屋 (1959) により光顕的に, 脊随神経郎 絒胞で認められている.

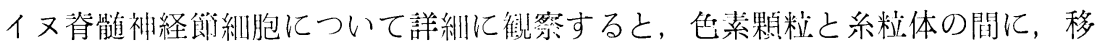
行型ではないかと思われる物体を認めることがある。乙れは糸粒体がやや萎縮 し，内部基質が密になって，cristae は発見困難となったものである（図 9，10. 11). Hess (1955) は，モルモットの春能神経節細胞で, 特に老令の動物に顕著に

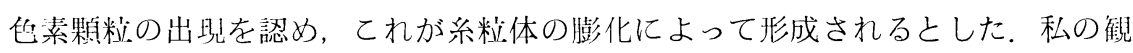
祭では，膨化した糸粘体と色素顆精との間には移行は認められないが，むしろ萎 縮した糸粒体が，色素の炎生母地となるのではないかと考えられる．Ito (1936)

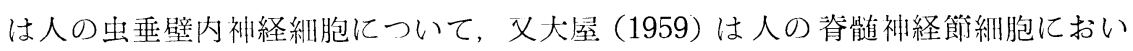
て, 光顕的に色素顆䊀の起原を系粒体に求めている. 乙の色素顆䊑の化学的性状 は，現在全く未知であり，人の神経紃胞等にみられた特異な集塊を作る色素顆粓 は, 球形の孤立した色素顆粒と, 化学的性状を異にするのではないかとも想像さ れる。

5, 神経微原線維，光学顕徵鏡による鍍銀標本の觀察に基づき, 古くから神経 紬胞内には縦横に走る原線維があり，乙れが束状をなして軸索内を縦走すると述 べられている，この原線維は神経原線維 (neurofibril) と呼ばれているが，てれに 相当するような光学顕徴鏡の可視䡉囲に入る䅅太い線維構造は, 電子顕微鏡的検

Figs. 13-15. Various types of pigment granule $(P)$ of nerve cells from dog's spinal ganglion (Fig. 13) and from human cerebral cortex (Figs. 14 and 15). The granule of ten consists of numerous smaller granules or droplets, some of which are converted into vacuoles.

Figs. 16-18. Infoldings (1) of plasma membrane into the satellite cell cytoplasm $(S)$. $G A$ ganglion cell, $N$ nucleus of a satellite cell. Small vesicles $(V)$ are often associated with plasma membrane infolding. Figs. 16 and 17 are obtained from dog's spinal ganglia, and Fig. 18 from rabbit spinal ganglion. 
索によっては, 神経細胞の perikaryonにも軸索にも発見できない, しかし遙かに 細い線維状構造は，常に perikaryon にも軸索にも発見し得るのであって，特に 後者では概ね軸索の長軸に平行に配列している（図6）。乙の微細線維は，光学顕 微鏡の神経原線維とは厳密に一致するあのでなく, 勿論光学顕微鏡の分解能を以 ては不可視の太さを有する。乙の線維構造を従来の神経原線維と区別して，神経 微原線維 (neurofilament) とよぶ。この微原線維は, 軸索に於て Schmitt と Geren (1950), Fenandez-Moran (1952), Hess と Lansing (1953) 等によって観察され, perikaryon に於ては Palay と Palade (1955) によって記載された。

私の雄察では, 春骾神経郎細胞の細胞質中 Nissl 物質, 糸粒体, Golgi 装置等に よって占められない細胞質基質中に，不定の方向に走る微原線維が存在し，その 太さは $100 \AA$ 或はそれ以下であるが（図 9,10), 電子密度が低く, 境界が不鮮明 であるから，正確な測定は困難である，屢々数本の微原線維が平行に集って束状 をなすこともあるが，その場合でも光顕により認め得べき太さにはならない．

軸索内に於ては，神経微原線維は概ね一致した方向に配列するが，厳密に長軸 に平行ではなく，屢々斜に走っている，しかもその方は約 $0.5 \mu の$ 幅をむって 方向が逆転し，恰も真田紐のように編目模様を作っている（図6)。乙の点筋細胞 における筋微原線維 (myofilameut) が整然と平行に配列するものと比較して, 極 めて顕著である。軸索内に於ては, 神経微原線維は一定の太さの束を作り, その束 がからみあってねじれているという感じを受ける。 ての束は, 光学顕微鏡により 命名された神経原線維に相当するか屯しれない。しかし束の形成は明瞭でなく， 束と束の間に間隙は見られない，従って光学顕微鏡的な意味の神経原線維は，か なり粗い周定によって生じた微原線維の凝集が束の間隙を大きくし，そこに銀が 沈着することによって生じた像であろう。しかしてれを全くの人工産物であると 決めてしまうことはできない，神経微原線維は明らかに実在し，その集束は容易 に人工的に招来されるのであるから，所謂「神経原線維」は人工的変形又は誇調 があるにしても，形態学的に意味のある像と考えられる。. Beams 等 (1952) が neurofibril の電顕像であるとした線維構造は，乙の棧の人工的変形を蒙った神経 微原線維の像であり，乙の意味でそれを neurofibril と呼ぶことは至当である。た だし，これがそのまま自然像であるとは考えられない.

私の観察した範囲内では。神経微原線維は特殊の構造を示さず，平滑な線維状 物である。しかるにVial (1958) はラットの坐骨神経に於て, 神経微原線維は

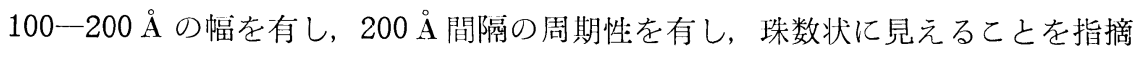
した。彼の写真を見ると, 神経微原線維はかなり粗い唒列を示し, 所々強く凝集 している，從って周期性の出見にはかなり強く间定の条件が影響していると思わ れる。

c) 紐胞膜.

春髄神経節細胞は， syncytium をなす外套絸胞によって完全に包まれているが 
（図 1), 時としては 2 個の神経細胞が共通の外套細胞被膜により包まれているこ とあある。大型明調細胞を包む外套細胞は，細胞質が薄く扁平に引き伸され，そ の細胞質の電子密度はやや大であるが，小型暗調細胞を包む外套細胞はやや厚く， 細胞質の密度はむしろ低く明るい，外套細胞と神経細胞の境界面には，明瞭な 2 重膜が存するが，内外 2 枚の膜はそれぞれ神経細胞と外套細胞の細胞膜と見做さ れる。乙の細胞境界は屢々複雑な経過を示し, 複雑に折れたたまれていることが あり，又2重膜のひだとなって，外套細胞の細胞質に突入しているととあある （図 16-18）。乙の满合，神経細胞側の細胞膜はこの突入に随わず，䧋入部を越え てほぼ平滑に保たれているが，外套細胞側の細胞膜は強く同細胞内に入り込む （図 16）。即ちこの構造は，外套細胞の細胞朕に生じた infolding であると考えら れる。陷入した細胞膜は，外套絒胞内で複雑に分技吻合することがあり，又その 周辺に必ず 20-50 m 神経紐胞側の細胞質内にも集合しているが，むしろ外套細胞内の方が多い．乙の ような細胞朕の陌入は，外套細胞の外表面にも見られることがある.

既に Hess（1955）はこの構造に着目し，やや羥細に記載している，その内容は， 姴在私がここに述べた所と殆んど一致するが, 彼は膜の陷入に伴って出刓する小 胞については触れていない. Anderson とVan Breemen (1958) はカエル (Rana

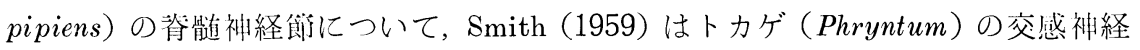
㓩について, 外套絒胞に小胞の出抯を認めているが, 絒胞膜陥人については言及 していない.

これらの構造が, 果して如何なる機能的意義を有するかについては, 從来の研 究者によっては全く論議されていない。乙の絒胞膜陌入と小胞に関しては，次の 3 点から考えることができる.

第 1 は, このような膜の複雑な走行と小胞は, 神経末端の synapse に於て, 屢 々認められることがあるということである, De Robertis と Bennett (1955) は。乙 のような小胞を，カエルとミミズの神経で発見して， synaptic vesicle と唱えた． 純諺態的な見地からは, 外套絸胞に出玩する小胞も, synaptic vesicle に非常に類 似している. しかし, 外套細胞は glia 要素に属し, 神経興奮伝導とは直㑕に関係 はない，父結合組織に面する外套細胞の外面の近くにも存在するととは, synapse との関係を肯定するような根拠を全く示さない.

第 2 に, このような膜の陌入は, Schwann 細胞に㕋々認められ, 無能線維に あっては, mesaxon を形成し, 有能線維では myelin 鞘の形成に与かる(Geren 1954, Robertson 1957-1958). 外套細胞は Schwann 細胞と極めて辺縁な関係にあ り, 神経䬦細胞の突起が屢々迁曲しつつ, その内部を貫通する事実から, mesaxon との関連も一応考虑に入れなければならない.しかし, Schwann 細胞の mesaxon 又は myelin 鞘の附近に, 前述した小胞の出現する事実の記戴された論文は末だ 見当らない，又外套細胞の細胞膜陥入が極めて単純な例では，単に短い距離の陷 
入の後盲端に終っているととがあり, 神経細胞の笑起と無関係であるとと, 又幸 にして外套細胞内に存する神経突起が横断された例にあっても, これと細胞膜陥 入との間に，明瞭な関係が求められないとと等から，乙の構造が mesaxon 等と相 同の構造とは睍在の所考えられない.

第 3 に, 細胞膜の陥入とこれに連続し, 或は随伴する小胞は, 屢々多量の水分 移動に関係する上皮細胞に認められている。乙れは腎尿細管上皮に於て最初に 発見され (Pease 1955), 萃蔵, 唾液腺等の腺紐胞 (Weiss 1953, Peare 1956), 脳室 脈絡丵上皮 (Maxwell と Pease 1956), 内耳血管条上皮 (Smith 1957), 汗腺細胞 (Kitamura と Kurosumi 1958, Kurosumi 等 1959)等で認められている. 又 Palade （1953）は毛細血管内皮細胞で，私がここで認めた同様な小胞を発見し，液体が毛 細血管壁を通過して運ばれる像であるとした。 Kurosumi 等 (1959) は汁腺の所 見に基いて, 細胞膜の陥入とおそらくその先端よりちぎれて生ずる小胞は, 液体 の移動に関係するものであるという.

外套細胞は神経細胞を包被して，乙れを保護すると同時に，後者の栄養保持に

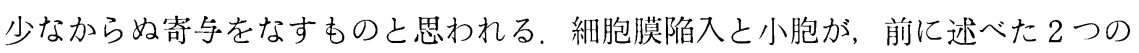
考察に於て充分にその意義を解明し得なかった以上，乙の第３の可能性が最む 強く支持されるであろう. おそらく, これらの構造は, 神経細胞の栄養保持のため に，外套細胞が液体を補給する玩象に関連ある構造であろうと思われる。

\section{III. 総 括.}

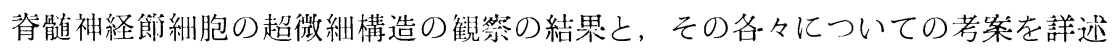

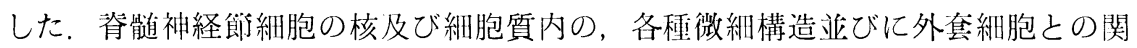
係等に言及した。

1. 脊髄神経節の細胞核は大きく電子密度が低い，核膜は小孔を有する二重膜 構造を有しているが，その特徵とする所は，乙の核膜に顆粒が附着することがな く常に平滑で, Nissl 物質の所見と比較して興味の深い点を強調した.

2. 核質の超微構造は，珠数状に連なる䊀子から成る線維 (chromonema) より 構成され，その螺旋構造が緩解して不归瞭となっている点が，神経紐胞の核の特 微と考えられる。しかし核質内の染色質集塊に於ては，螺旋構造が認められる.

3. 核小休は限界膜を有せず，紐状の nucleolonema から成り，乙れは顆粘の連 結により生じた線維状物が, 充実性の螺旋束を作っており, この線維束が特に強 くねじれた部位に，nucleolonemaの結節を形成するもののようである.

4. Nissl 物質は, 微細顆精の集団からなる顆精小塊と, endoplasmic reticulum （ER）に属する胞状体から成るが，乙の胞状体の膜には顆粒が附着することなく， 所謂 rongh surfaced ER と, smooth surfaced ER の中間的存在と考えられる. 顆 粒小塊は立体的に球形の配列をなしているものであろうと考えられ，從来のよう に単純な rough surfaced ER に属すと決定出来ない. Nissl 顆粒の配列と, 核小体 
の顆精配列は全く異る.

5. Golgi 装置の基本的構造は, Golgi 小胞であろうと考えられ, Golgi 大胞は その膨大により, 又 Golgi 層板は珠数状に連なった小胞の融合によって生ずると 思われる。 Golgi 装置は，Nissl 物質とは顆粓小塊が全く認めら机ない点で区別さ れる。

6. 神経䬣細胞の糸粘体は球形，又は短桿状をなし，内部に細管状の cristae mitochondriales を有する。系粒体より出紫顆料への転化の可能性が考えられ， そ のための糸精体数の減少は，糸料体そのものの分裂によって補われると思われ る.

7. 神経微原線維の束状の棈造と走行が不規則な点を挙げ，これと神経原線維 との関係を考察した。

8. 神経節細胞の細胞質と外套細胞間の 2 重の細胞膜のうち, 外套細胞側の細 胞腫が複雑な入り組み, 所謂 infolding を形成するととと, それに伴って出覞す る小胞との関係から，乙れらの形象が神経細胞の栄養保持という外管紐胞の機能 に関連あるものと推定した。

本論文を故稻見教授の瑟前淎げます。

本研究に際し御校閲をたま方った。解剖学教室付東教授, 精神神経学教室台教授飞感㴬の 意をささげます。果終始御指導を下された第 1 解剖学教室黑住助教授及び同教室只の諸兄に 深く感謝します。

\section{Author's Aisstract.}

Normal spinal ganglia of the rabbit and the dog were observed with the electron microscope. Nerve cells and satellite cells and their mutual relationship were especially studied.

1. The nucleus of the spinal ganglion nerve cell is extremely large and less in electron density. The nuclear envelope shows a double structure, whose outer membrane is smooth but not attached with granules. This fact is of great interest comparing with the fact that the membrane in NISSL substance is also smooth.

2. The karyoplasm consists of filaments (chromonemata) composed of small Particles arranged in a row like a stringe of beads. In the nerve cell, helical structure of chromonemata is generally loosened and indistinct, but it is evident at the portion of densely aggregated chromatin.

3. Well developed nucleoli have no limiting membrane, and made up of tangled skein, the nucleolonema, which consists of more than ten filaments (primary nucleolonemata) twisted helically. Node-like portions of nucleolonema may be manifested by an extremely strong twisting of such a helical bundle.

4. The NISSL substance is a mixture of clusters of small dense granules and vacuoles belonging to the endoplasmic reticulum. The surface of the membrane of such vacuoles is smooth. The granules are not generally attached to the membrane surface. Rarely clusters of granules may attach, but even in this case each granule does not attach solitarily. Therefore, the NISSL substance may be called as an 
intermediate between the rough and smooth types of the endoplasmic reticulum and not as a typical rough surfaced variety.

Clusters of granules is thought to be three-dimensionally of a globular arrangement, whose center may be lacking in granules. The disposition of granules in the NISSL substance quite differs from that in the nucleolus.

5. The GOLGI apparatus can be distinguished from the NISSL substance by the absence of clustered granules. The fundamental structure of the GOLGI apparatus may be vesicles. Jarge vacuoles may be formed by the expansion of vesicles, and the lamellae from the fusion of neighboured vesicles arranged in rows like strings of beads.

6. Mitochondria of the spinal ganglion cell are spherical and rod-shaped, and contain tubular cristae mitochondriales. Transformation from mitochondria into pigment granules is suggested. Decrease of mitochondria in number due to their conversion into pigment may be supplied by fission of mitochondria themselves.

7. In the cytoplasm of the perikaryon, neurofilaments run in all directions, but in the axon they are arranged in general longitudinally, and consist of bundles which are twisted with one another.

8. The intercellular margin between the nerve cell and the satellite cell is seen as a double membrane, each of them belongs to one of the neighbouring cells. Plasma membrane of satellite cell side frequently invades into the cytoplasm of the latter, forming double membraned folds. Small vesicles are of ten associated to such infoldings. These features may be related to the fluid-transport for mainteining the nutrition of nerve cells.

\section{文献.}

Afzelius, B. A.: The ultrasturcture of the nuclear membrance of sea urchin oocyte as studied with the electron microscope. Eep. Cell Res. 8 (1959). P. 147-158. - Amano, S.: The sturcture of the centrioles and spindle body as observed under the electron and phase contrast microscopes. Cytologia 22 (1957). P. 193-212. -- Anderson, E. and v. L. Van Breemen.: Electron microscopic observations on spinal ganglion cells of Rana pipience after injection of malononitrile. J. biophys. biochem. Cytol. 4(1958) P. 83-86. - Baker, J. R.: The sturucture and chemical composition of the Golgi element. Quart. J. micr. Sci. 85 (1944). P. 1-71. - Beams, H. W., V. L. Van Breemem, D. M. Newfang and T. C. Evans.: A correlate study on spinal ganglion cells and associated nerve fibcrs with the light and electron microscopes. J. comp. Neur. 96 (1952). P. 249-281. - Belt, W. D. and D. C. Pease : Mitochondrial structure in sites of steroid secretion. J. biophys. biochem. Cytol. 2 (1956). Suppl. P. 369-374. - Bernhard, W., F. Haguenau et Ch. Oberling : L'ultrastructure du nucléole de quelques cellules animales révèlèe par le microscope électronique. Experientia 8 (1952). P. 58-59. - Bernhard, W., A. Bauer, A. Gropp, F. Haguenau et Ch. Oberling : L'ultrastructure du nucléole de cellules normales et cancereuses ; etude au microscope électronique. Exper. Cell Res. 9 (1955). P. 88-100. — Borysko, E. and F. B. Bang : Electron microscope observations on nucleolar structure. J. appl. Physics 23 (1952). P. 163. - Callan, H. G. and S. G. Tomlin : Experimental studies on amphibian oocyte nuclei. I. Investigation of the structure of the nuclear membrane by means of the electron microscope. Proc. roy. Soc. B. 137 (1950). P. 367-378. - Chou, J. T. Y. and G. 
A. Meek : The ultra-fine structure of lipoid globules in the neurones of Helix aspersa. Quart. J. micr. Sci. 99 (1958). P. 279-284. - Dalton, A. J. and M. D. Felix : Studies on the Golgi substance of the epithelial cells of the epididymis and duodenum of the mouse. Amer. J. Anat. 92 (1953). P. 277-305. - Da1ton, A. J. and M. D. Felix : Cytologic and cytochemical characteistics of the Golgi substance of epithelial cell of the epididymis. Amer. J. Anat. 94 (1954). P. 171-207. — De Rodertis, E. and H. S. Bennett : Some features of the Submicroscopic morphology of synapses in frog and earthworm. J. biophys. biochem. Cytol. 1 (1955). P. 47-58. - Estable, C. y J. R. Sotelo : Una neuva estructura celular : el nucleolonema. Publ. Inst. Invest. Ciencias Biol. 1 (1951). P. 105-126. - Fernandez-Moran, H.: The submicroscopic organization of vertebrate nerve fibers. Exp. Cell Res. 3 (1952). P. 282-359. - Geren, B. B.: The formation from the Schwann cell surface of myelin in the peripheral nerves of chick embryos. Exp. Cell Res. 7 (1954). P. 558-562. - Grasse, P. P. and N. carasso : Ultra-structure of the Golgi apparatus in protozoa and metazoa (somatic and germinal cells). Nature. 179 (1957). P. 31-33. - Haguenau, F.: The ergastoplasm: Its history, ultrastructure, and biochmistry. Intern. Rev. Cytol. 7 (1958). P. 425-483. Haguenau, F. et E. Bernhard : L’appareil de Golgi dans les cellules normales et cancéreuses de vertébrés. Rappel historique et étude au microscope électronique. Arch. d'Anat. micr. et de_Morph. exp. 44 (1955). P. 27-55. - Hess, A.: The fine structure of young and old spinaI ganglia. Anat. Rec. 123 (1955). P. 399-424. - Hess. A. and Lansing, A. I.: The fine structure of Peripheral nerve fibers. Anat. Rec. 117 (1953). P. 117-175. - Hon jin, R.: Ultrastructure of the Golgi apparatus of the nerve cells. Fol. anat. jap. 29 (1955). P. 117-132. 一本陣良平：神経組織の雀子顕微鏡的研究. 紶合医学. 14 (1957). 頁 673-683. 一 Hossack, J. and G. M. Wyburn : Electron microscopic studies of spinal ganglion cells. Proc. roy. Soc. Edinburgh. 65 (1953-54). P. 239-250. - Horstmann, E. und A. Knoop : Zur Struktur des Nucleolus und des Kernes. Z. Zellforsch. 46 (1957). S. 100-107. - Ito, T.: Zytologische Untersuchungen über die intramuralen Ganglienzellen des Verdauungstraktus. Über die Ganglienzellen der menschlicher Wurmfortsätze u.s. w. Fol. anat. jap. 14 (1936) S. 621-663. - Kitamura, T. and K. Kurosumi : Occurrence of foldings of plasma membrane ( $\beta$-cytomembrane) in cells of pig's capal organ as revealed by electron microscopy. Nature. 181 (1958). P. 489. - Körner, F.: Variations statische Untersuchungen über die größe der Kerne und der Kernkörperchen menschlichen Nervenzellen. Z. mik. -anat. Forsch. 42 (1937). S. 81-114. - Beobachtungen über den Austritt geförmter Substnzen aus dem Kernkörperchen beim Menschlichen Nervenzellen. Z. mikr. -anat. Forsch. 42 (1937). S. 362-378. - 黒住一昌：卵細胞微細構造の笔子顕微鏡的研究. 解剖喆. 32 (1957) 頁 175-226. 一 Kurosumi, K.: Electron microscope studies on mitosis in sea-urchin blastmeres. Protoplasma 49 (1958). P. 116-139. 一黒住一昌, 秋山洋一：㤥小体の超微細構造について. 日組録. 14 (1958). 頁 291-308. 一 Kurosumi, K., T. Kitamura and T. Iijima: Electron microscope studies on the human axillary apocrine sweat glands. Arch. his. Jap. 16 (1959). P. 523-566. 一 黒住

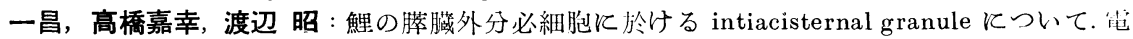
子頙微鏡. 8 (1959). 頁 48-54. - Marinesco, G.: Recherches sur le noyeau et le nucléole de la cellule nerveuse à l'état normale et pathologique. J. Psychol. u. Neur. 5 (1905). P. 151172. - Maxwell, D. S. and D. C. Pease : The electron microscopy of choroid plexus. J. biophys. biochem. Cyto. 2 (1956). P. 467-474. - Munger, B. L.: A phase and electron microscopic study of cellular differentiation in pancreatic acinar cells of the mouse. Amer. J. Anat. 103 (1958). P. 1-33. 一大屋正夫：成人敷神経節細胞の細胞学的研究. 日組録. 18 (1959). 印㑬中. - Palade, G. E.: The fine structure of mitochondria. Anat. Rec. 114 (1952). P. 427-452. - Fine structure of blood capillaries. J. appl. Phys. 24 (1953). P. 1424. - Studies on the endoplasmic reticulum. II. Simple disposition in cells in situ. J. biophys. biochm. Cytol. 1 (1955). P. 567-582. - Intracisternal granules in the exocrine cells of the pancreas. J. biophys. biochem. Cytol. 2 (1956a). P. 417-421. - The endoplasmic reticu- 
lum. J. biophys. biochem. Cytol. 2 (1956 b). Suppl. P. 85-98. - Palade, G. E. and Claude A.: The nature of Golgi apparatus. I. Palallelism between Golgi aparatus and intracellular myelin figues. J. Morph. 85(1949). P. 35-69. - II. Identification of the Golgi apparatus with a complex of myelin fugure. J. Morph. 85 (1949). P. 71-111. - Palsde, G. E. and Siekevitz P.: Pancreatic microsome, an intgrated morphological and biochemical study. J. biophys. biochem. Cytol. 2 (1957). P. 671-690. - Parat, M. et J. Painleve: Appareil réticulaire de Golgi, trophosponge de Holmgren et vacuome. Compt. roy. Acad. Sci. T. 179 (1924). - Pease, D. C.: Electron microscopy of the tublar cells of the kidney cortex. Anat. Rec. 121 (1955). P. 723-743. - Infolded basal plasma membranes found in epithelia noted for their water trnsport. J. biophys. biochem. Cytol. 2 (1956). Suppl. P. 203-208. Porter, K. R.: Observation on a submicroscopic basophilic component of cytoplasm. J. Exp. Med. 97 (1953). P. 727-750. - Rhode, E.: Untersuchungen über den Bau der Zelle. I. Kern und Kernkörperchen. Z. wiss. Zool. 73 (1903). S. 497-682. — Ries, E.: Zur Histophysiologie des Mäusen Pankreas nach Lebendbeobachtung, Vitalfärbung und Stufenuntersuchung. Z. Zellforsch. 22 (1935). S. 523-585. - Robertson, J. D.: New observation on the ultrastructure of the Membranes of frog peripheral nerve fibers. J. biophys. biochem. Cytol. 3. (1957). P. 1043-1048. - Robertson, J. D.: Structural alteration in nerve fibers produced by hypotonic and hypertonic solutions. J. biophys. biochem. Cytol. 4, (1958). P. 349-364. - Scharf,J.H.: Zur Frage der Grenzmembran der Spinalganglienzellen. Acta Neuroveget. 3 (1951). S. 498-506. - Scharf, J. H.: Polarisationsoptische Untersuchungen an markhaltigen Ganglienzellen in der wirbeltierrehe und beim Menschen. u. s. w. Mikroskopie (Wien). 7 (1952). S. 174-190. - Scharf, J. H.: Sensible Ganglien. Nervensystem. Möllendorffs Handbuch der mikroskopischen Anatomie des Menschen. Bd. 4, Tl. 3. 1958. - Sch mitt, F. O. and Geren B. B.: The fibrous structure of the nerve axon in relation to the localization of 'Neurotubules'. J. exp. Med. 91 (1951). P. 499-504. — Sjöstrand, F. S.: Electron microscopy of mitochondria and cytoplasmic double membranes. Nature 171(1953). P. 30-32. - Electron microscopy of cells and tissues. Physical Techniques in Biological Research. Vol. 3. P. 241. N. Y., Academic Press, 1956. - Sjöstrand, F. S. and V. Hanzon : Ultrastructure of Golgi apparatus of exocrine cells of mouse pancreas. Exp. Cell Res. 7(1954). P. 415429. - Sjöstrand. F. S. and J. Rhodin : The ultrastructure of the proximal convoluted tubules of the mouse kidney as revealed by high resolution electron microscopy. Exp. Cell Res. 4(1953). P. 426-456. - Smith, C. A.: Microscopic structure of the utricle. Ann. Otol. Rhinol. Laryngol. 65 (1956). P. 450-470. - Structure of the stria vascularis and the spiral prominence. Ann. Otol. Rhinol. Laryngol. 66 (1957). P. 521-536. - 'Reticular' and 'areti-cular' Nissl bodies in sympathetic neurons of a lizard J. biophys. biochem Cytol. (1959). P. 77 84. 一田中春高：淋巴腺及胸腺飞於ける淋巴系細胞の電子顕微鏡的研究. 日血会誌20 (1957) 頁 237-245. 一 Vial, J. D.: The early changes in the apoplasm during Wallerian degeneration. J. biophys. „biophys. biochem Cytol. 25 (1958). P. 551-556. — Watson, M.L. : The nuclear envelope, its structure nd relation to cytolasmic membranes. J. biophys. biochem. Cytol. 1 (1955). P. 257-269. - The ergastoplasm, its fine struture and relation to protein synthesis as studied with the electron microscope in the pancreas of Swiss albino mouse. J. exp. Med. 98 (1953). P. 607-618. - Yasuzumi, G., T. Sawada, R. Sugihara, M. Kiriyama and M. Sugioka : Electron microscope researches on the ultrastructure of nucleoli in animaI tissues. Z. Zellforsch. 48 (1958). P. 10-23. 